\title{
Perbanyakan Tanman Panili (Vanilla planifolia Andrews) Secara Stek dan Upaya untuk Mendukung Keberhasilan serta Pertumbuhannya
}

\author{
Vanilla Plany Propagation by Cuttings and Efforts to Supports the Succes of Plant and Growth
}

\author{
Nurholis \\ Prodi Agroteknologi Fakultas Pertanian Universitas Trunojoyo Madura \\ Jl. Raya Telang PO BOX 2 Kamal Bangkalan Madura \\ E-mail: nurholis_xtr28@yahoo.com
}

\begin{abstract}
Seedling is one of important component in vanilla cultivation. Growth and living of stem cutting at nursery are contributing factor in produce and seedling supply. The purpose of this paper was to get an information about the results of research that has been done and other supporting information about plant propagation cuttings and cuttings efforts to support the success of plant growth. Growth rate and success of plant propagation of cuttings in cuttings in the nursery are influenced by cultivation technology and environmental conditions, so should adopt appropriate cultivation technology and pay attention to the suitability of the environment that meet the requirements of growing crops vanilla. Efforts to support the success and growth of cuttings of vanilla have been undertaken in various researches to reduce the existing constraints in the practice of cultivation, especially nursery by using cutting material. For example, in the effort to overcome the limitations of cutting material with the use of short cuttings, increase growth by using plant growth regulator, to overcome the availability of nutrients with the fertilization either through soil or leaf, and efficiency in nutrient uptake using mycorrhiza.
\end{abstract}

Keywords: seedlings, cultivation technology, Vanilla planifolia, vegetative

\begin{abstract}
ABSTRAK
Salah satu faktor penentu keberhasilan pengembangan dan pengusahaan tanaman panili antara lain bibit yang baik. Tingkat pertumbuhan dan keberhasilan perbanyakan tanaman panili di pembibitan menjadi faktor pendukung dalam menghasilkan dan penyediaan bibit. Makalah ini bertujuan untuk mendapatkan informasi baik mengenai hasil penelitian yang telah dilakukan maupun informasi pendukung lainnya mengenai perbanyakan tanaman panili secara setek dan upaya untuk mendukung keberhasilan serta pertumbuhannya. Tingkat pertumbuhan dan keberhasilan perbanyakan tanaman panili secara setek di pembibitan di antaranya dipengaruhi oleh teknologi budidaya dan kondisi lingkungan, sehingga harus mengadopsi teknologi budidaya yang tepat serta memperhatikan kesesuaian lingkungan yang memenuhi persyaratan tumbuh tanaman panili. Upaya untuk mendukung keberhasilan serta pertumbuhan setek panili, telah dilakukan berbagai penelitian untuk mengurangi kendala-kendala yang ada dalam praktek budidaya khususnya pembibitan dengan menggunakan bahan setek. Misalnya dalam upaya menanggulangi keterbatasan bahan setek dengan penggunaan setek pendek, meningkatkan pertumbuhan dengan penggunaan zat pengatur tumbuh, mengatasi ketersediaan unsur hara dengan pemupukan baik lewat tanah maupun daun, dan efisiensi dalam penyerapan hara dengan menggunakan mikoriza.
\end{abstract}

Kata kunci: bibit, teknologi budidaya, Vanilla planifolia, vegetatif

\section{PENDAHULUAN}

Panili (Vanilla planifolia Andrews) merupakan salah satu tanaman introduksi yang berasal dari Meksiko dan Amerika Tengah yang buahnya banyak digunakan dalam industri makanan, minuman, farmasi, dan kosmetik karena buahnya mengandung vanillin $\left(\mathrm{C}_{8} \mathrm{H}_{8} \mathrm{O}_{3}\right)$ mengeluarkan aroma khas. Panili saat ini sudah berkembang dan dibudi dayakan di daerah tropik. Di Indonesia, panili telah menyebar luas hampir di seluruh wilayah dengan daerah sentra produksi di daerah Jawa, Bali, Sulawesi dan Sumatera. Hal ini telah menempatkan panili sebagai komoditi ekspor yang bernilai tinggi dan berpotensi dalam penerimaan devisa negara (Udarno dan Hadipoentyanti 2009). 
Bibit merupakan salah satu faktor penentu keberhasilan dalam upaya pengembangan dan pengusahaan tanaman panili. Tingkat pertumbuhan dan keberhasilan perbanyakan tanaman panili di pembibitan menjadi faktor pendukung dalam menghasilkan dan penyediaan bibit. Tanaman panili dapat diperbanyak secara generatif maupun vegetatif, perbanyakan secara generatif dengan menggunakan benih memerlukan teknologi khusus karena benihnya kecil, berkulit keras dan cadangan makanannya sedikit. Oleh sebab itu, tanaman panili secara umum diperbanyak secara vegetatif menggunakan bahan setek yang terdiri atas 1 sampai 3 ruas. Menurut Lawani (1995) perbanyakan tanaman panili dilakukan secara vegetatif karena mudah dilakukan, cepat berproduksi, dan juga memiliki kelebihan sifat sama seperti induknya.

Produk panili hampir seluruhnya ditujukan untuk ekspor, terdapat berbagai masalah dalam sistem agribisnis mulai dari hulu sampai hilir. Paket teknologi yang ada untuk pengembangan tanaman panili saat ini masih terbatas dan perlu ditingkatkan (Ditjenbun 2008). Oleh sebab itu, perlu disusun program penelitian tanaman panili di bidang Agronomi terutama untuk menghilangkan atau mengurangi kendala-kendala dalam pembudidayaan tanaman panili tersebut. Salah satunya mengenai praktek budidaya khususnya pembibitan dengan menggunakan bahan setek. Masalah-masalah yang menyangkut penggunaan panjang bahan setek, umur fisiologis, posisi ruas, penggunaan mikoriza, pemupukan, penggunaan zat pengatur tumbuh (ZPT) telah dicoba untuk diatasi dengan melakukan penelitian sejak beberapa tahun terakhir dalam upaya mendukung keberhasilan serta pertumbuhannya. Makalah ini bertujuan untuk mendapatkan informasi baik mengenai hasil penelitian yang telah dilakukan maupun informasi pendukung lainnya mengenai perbanyakan tanaman panili secara setek dan upaya untuk mendukung keberhasilan serta pertumbuhannya.

\section{BAHAN DAN METODE}

Pengumpulan data atau informasi dari berbagai sumber pengetahuan, baik dari bahan bacaan dan hasil-hasil penelitian berupa skripsi, tesis, disertasi, jurnal, maupun prosiding hasil seminar yang berhubungan dengan obyek studi.

\section{HASIL DAN PEMBAHASAN}

\section{PERBANYAKAN PANILI SECARA VEGETATIF}

Panili yang umum dibudidayakan dan komersial hanya satu jenis yaitu Vanilla planifolia dan perbanyakannya biasanya dilakukan secara vegetatif dengan setek (Udarno dan Hadipoentyanti 2009). Cara vegetatif banyak dilakukan untuk tujuan komersial dengan menggunakan setek. Keuntungan yang diperoleh pada perbanyakan vegetatif yaitu sifat-sifat pohon induknya dipertahankan, cepat berproduksi, mudah dilaksanakan dan relatif murah.

\section{BAHAN TANAMAN}

Pohon induk merupakan peranan penting dalam sertifikasi benih atau bahan tanaman yang disebarkan kepada petani, sehingga dapat terjamin identitas dan kemurniannya. Tanaman dapat dipilih sebagai pohon induk apabila varietasnya unggul dan sehat. Pohon induk yang sehat ditandai oleh warna daunnya yang bersih, tanpa tanda-tanda kekurangan unsur hara bebas serangan hama dan penyakit serta dalam pertumbuhan aktif. Varietas Pania 1 dan Pania 2 dapat digunakan sebagai pohon induk karena memiliki potensi produksi dan ketahanan terhadap faktor lingkungan (Ditjenbun 2008). Bahan setek yang baik yaitu mempunyai buku-buku yang agak rapat letaknya, berwarna hijau segar, muda dan berasal dari tanaman yang subur. Bahan Setek yang diambil dari pohon induk, didiamkan selama kurang lebih satu minggu agar luka bekas pangkasan kering dan patogen tidak mudah masuk (Tjahjadi 1995). Menurut Suparman dan Evizal (1987) panili dapat diperbanyak melalui setek satu ruas yang diambil dari ruas ke-4 sampai ke-12 dari pucuk, metode perbanyakan setek satu ruas akan sangat menghemat penggunaan setek dan dapat mengatasi keterbatasan bahan tanam.

Bahan setek diambil dari sulur-sulur yang belum pernah mengeluarkan bunga pada pertanaman yang sudah pernah berbuah. Pengambilan bahan setek sebaiknya pada pertengahan musim hujan, dan 6 minggu sebelum sulur diambil untuk benih. Untuk mendapatkan bahan setek dengan daya tumbuh yang baik maka $20 \mathrm{~cm}$ bagian pucuknya dibuang atau dipotong. Hal ini dilakukan agar karbohidrat, asam-asam amino, vitamin dan zat pengatur tumbuh tidak banyak terpakai untuk pertumbuhan dan tertimbun dibagian sulur tanaman (Hadipoentyanti et al. 2007). Menurut Somantri dan Evizal (1987) perlakuan pemotongan pucuk (topping) berpengaruh besar terhadap mutu bahan setek. Pengaruh pemotongan pucuk terhadap panjang tunas, panjang akar, dan jumlah daun di tampilkan pada tabel 5.

Pengambilan sulur dilakukan 4 sampai 6 minggu setelah pemotongan sulur. Sulur yang telah diambil dipotong-potong menjadi 2 buku dengan menyisakan satu daun pada buku teratas, dan akarakar lekat dibuang atau setek pendek 1 ruas berdauan tunggal (Hadipoentyanti et al. 2007).

Kebutuhan bahan tanam yang diperlukan untuk pengembangan tanaman panili dengan menggunakan bibit dari setek pada 1 ha lahan ditentukan oleh jumlah ruas setek dan jarak tanam yang digunakan. Bahan tanam untuk pembibitan dengan menggunakan setek secara umum terdiri atas 1 sampai 3 ruas dengan panjang 1 ruas setek 12 sampai 
$15 \mathrm{~cm}$. Bibit yang sudah siap tanam, ditanam pada lahan dengan berbagai jarak tanam yaitu $2.5 \mathrm{~m} \times 1.5 \mathrm{~m}, 2 \mathrm{~m} \times 1.5$ m, $1.5 \mathrm{~m} \mathrm{x} 1.5 \mathrm{~m}, 2 \mathrm{~m} \times 1 \mathrm{~m}$, dan $1.5 \mathrm{~m} \mathrm{x} 1 \mathrm{~m}$ (Rosman et al. 1989). Kebutuhan bahan tanam bibit panili untuk 1 ha lahan di tampilkan pada tabel 6.

\section{MEDIA TANAM}

Pembibitan panili secara umum menggunakan polybag yang berisi media tanam. Jenis media tanam yang bisa digunakan sebagai media pembibitan diantarnya adalah tanah, arang sekam, pasir, cocopeat, pellet jiffy, cacahan jerami padi, sabut kelapa, dan arang kayu.

Hasil penelitian Mariska et al. (1987) menunjukkan bahwa penggunaan media pasir, campuran tanah dan pupuk kandang, sabut kelapa dan pellet jiffy memberikan hasil yang berbeda. Penggunaan campuran media tanah dan pupuk kandang dengan perbandingan (volume) 1:1 memberikan hasil yang cenderung lebih baik pada parameter panjang tunas, persentase tumbuh, panjang akar dan jumlah akar dibandingkan dengan media lainnya. Selanjutnya hasil penelitian Rosman et al. (1992) menunjukkan bahwa penggunaan media jerami padi, sabut kelapa dan arang kayu dapat menyediakan unsur hara dan air serta aerasi yang baik untuk pertumbuhan tunas setek panili sehingga dapat menghasilkan tunas dengan kecepatan yang sama dengan media tanah. Dhalimi (2003) menambahkan bahwa penggunaan media campuran tanah, arang sekam, dan pupuk kandang sebagai media tanam pembibitan panili dapat meningkatkan pertumbuhan yang ditunjukkan oleh parameter tinggi tanaman, jumlah daun dan diameter batang pada 4 sampai 16 minggu setelah tanam.

Media tanam yang digunakan secara umum terdiri atas komposisi tanah, arang sekam dan pupuk kandang dengan perbandingan (volume) 2:1:1. Komposisi media tanam tersebut harus memberikan lingkungan tumbuh yang sesuai dan dapat mendukung pertumbuhan setek tanaman panili. Soepardi (1983) menyatakan bahwa media tanam merupakan syarat tumbuh yang penting dan salah satu faktor yang mempengaruhi pertumbuhan tanaman sebagai tempat tumbuh, media perakaran, dan sumber unsur hara. Karakteristik media tanam yang baik memiliki sifat fisik dan sifat kimia yang mampu menopang fisik tanaman dan mampu menyuplai kebutuhan hara tanaman. Menurut Ingels (2000) media tanam yang tepat merupakan salah satu syarat keberhasilan pertumbuhan tanaman khususnya penanaman dalam wadah. Keberhasilan pertumbuhan tanaman ditentukan oleh pertumbuhan dan perkembangan akarnya. Akar tanaman hendaknya berada pada suatu lingkungan yang mampu memberi dukungan struktural yang memungkinkan absorbsi air, drainase, dan ketersediaan nutrisi. Selanjutnya Acquaah (2009) menyatakan bahwa media tanam yang baik harus memiliki kemampuan menahan air, struktur gembur, aerasi dan drainase yang baik, $\mathrm{pH}$ yang sesuai dengan jenis tanaman dan mengandung unsur hara penting yang tersedia untuk mendukung pertumbuhan tanaman.

\section{PEMBIBITAN}

Kondisi lingkungan pembibitan harus memenuhi persyaratan tumbuh tanaman panili, seperti kelembaban udara $60-75 \%$, suhu $25-31{ }^{\circ} \mathrm{C}$ dan $30-50 \%$ intensitas cahaya matahari. Penggunaan setek 1 ruas dalam pembibitan dilakukan dalam upaya mengatasi keterbatasan bahan tanam. Bibit yang tumbuh setelah 4 bulan atau mempunya 5 sampai 7 ruas dari setek 1 ruas di pembibitan, dapat ditanam dilapang. Cara yang lebih adalah pembibitan dilakukan di dalam kantong plastik atau polybag ukuran 20 x $15 \mathrm{~cm}$ yang diisi media campuran tanah dan pupuk kandang dengan perbandingan volume $2: 1$. Sulur tanaman panili yang sehat dipotong menjadi setek satu ruas. Bagian pangkal setek dipotong di bawah bagian buku (tanpa daun) dan bagian ujung dipotong di atas buku yang berdaun (Zaubin et al. 1994).

Setek disortir dengan cara membuang setek yang berpenampilan jelek misalnya batang dan daunnya berwarna kuning, bercak-bercak putih-hitam. Sebelum ditanam seteksetek dicuci terlebih dahulu dengan air, kemudian direndam dalam larutan fungisida dengan konsentrasi $0.2 \%-0.3 \%$ selama 20-30 menit dan dikering anginkan selama 1 sampai 2 hari agar luka bekas potongan mengering sehingga dapat mengurangi pembusukan batang ketika ditanam (Ditjenbun 2008). Untuk merangsang dan mempercepat pembentukan akar serta untuk meningkatkan jumlah kualitas akar pada setek panili dapat digunakan zat pengatur tumbuh auksin.

Pemeliharaan setek yang penting dilakukan adalah penyiraman setiap hari, pelaksanaan penyiraman dilaksanakan pada pagi hari dan disesuaikan dengan kondisi curah hujan. Setek mulai bertunas kira-kira setelah 1 bulan, apabila setek telah mempunyai 1 sampai 2 daun maka setek perlu diberikan pemupukan lewat daun. Penyemprotan $2 \mathrm{~g}$ $\mathrm{L}^{-1}$ Gandasil D dilakukan setiap 1 sampai 2 minggu sekali (Dwiwarni 1989). Penyemprotan pupuk daun yang paling efektif dilakukan pada waktu sore atau malam hari, antara jam 16.00 sampai 20.00. Apabila sulur mulai memanjang, maka perlu dipasang tegakan dari belahan bambu untuk tempat memanjat sulur. Sulur yang memanjat perkembangan diameter batang dan luas daun akan lebih baik dari pada sulur yang menjalar. Bibit yang telah mempunyai panjang sulur antar 5 sampai 7 ruas maka bibit panili tersebut siap dipindahkan kelapang (Zaubin et al. 1994). 
Tabel 5. Pengaruh pemotongan pucuk terhadap panjang tunas, panjang akar, dan jumlah daun

\begin{tabular}{llll}
\hline Perlakuan & Panjang tunas & Panjang akar & Jumlah daun \\
\hline Kontrol & 4.76 & 43.89 & 1.4 \\
Topping 4 minggu & 10.88 & 50.73 & 2.89 \\
Topping 6 minggu & 13.23 & 46.74 & 3.05 \\
\hline
\end{tabular}

Sumber: Somantri dan Evizal (1987)

Tabel 6. Kebutuhan bahan tanam (m) bibit panili untuk 1 ha lahan.

\begin{tabular}{lllccc}
\hline Setek & Jarak tanam $(\mathrm{m})$ & & & \\
& $2.5 \times 1.5$ & $2 \times 1.5$ & $1.5 \times 1.5$ & $2 \times 1$ & $1.5 \times 1$ \\
\hline 1 ruas & \pm 400 & \pm 500 & \pm 666 & \pm 750 & \pm 1000 \\
2 ruas & \pm 800 & \pm 1000 & \pm 1332 & \pm 1500 & \pm 2000 \\
3 ruas & \pm 1200 & \pm 1500 & \pm 1998 & \pm 2250 & \pm 3000 \\
\hline
\end{tabular}

Pembibitan panili yang dilakukan di dalam kantong plastik atau polybag memiliki kelebihan diantaranya pemindahan bibit sewaktu penyaluran dan penanaman di lapang tidak diperlukan lagi, tidak terjadi transplanting shock pada waktu penanaman yang disebabkan oleh gangguan pada akar, bibit dapat langsung disalurkan bila telah cukup umur, dan relatif tidak memerlukan biaya penyiangan (Rosman et al. 1989).

\section{UPAYA UNTUK MENDUKUNG KEBERHASILAN SERTA PERTUMBUHAN SETEK PANILI}

\section{KESESUAIAN IKLIM DAN LAHAN}

Upaya dalam mendukung pengembangan tanaman panili di Indonesia, berbagai penelitian telah dilakukan. Tahun 1985 telah dipelajari karakteristik lahan dan iklim yang dikehendaki oleh tanaman panili secara nasional sebagai langkah awal dalam upaya pengembangan tanaman panili. Menurut Hadipoentyanti et al. (2007) iklim merupakan salah satu faktor yang mempengaruhi pertumbuhan dan perkembangan tanaman. Curah hujan yang dikehendaki oleh tanaman panili adalah 1000-2000 $\mathrm{mm} /$ tahun yang terbagi rata selama 8-9 bulan basah diikuti dengan bulan kering (curah hujan 60-90 mm/bulan) selama 3-4 bulan. Hari hujan yang diinginkan adalah 150-180 hari/tahun, suhu udara $20-30{ }^{\circ} \mathrm{C}$ dan kelembaban udara $65-$ $75 \%$. Tanaman panili dapat tumbuh dan berproduksi pada ketinggian tempat 0-1200 m dpl, namun untuk tujuan komersil sebaiknya diusahakan pada ketinggian tempat 0$600 \mathrm{~m}$ dpl. Semakin tinggi tempat maka suhu dan kelembaban makin tinggi, hal ini selain akan menguntungkan pertumbuhan jamur patogen tanaman juga akan menurunkan mutu polong. Selanjutnya Mansur (2009) menyatakan bahwa intensitas radiasi matahari yang dibutuhkan oleh tanaman panili antara 30-50\%. Tanaman panili tidak dapat tumbuh optimal bila tingkat naungan terlalu tinggi atau bila cahaya kurang. Sebaliknya, jika tingkat naungan terlalu rendah dapat mendorong berkembangnya penyakit busuk pangkal batang. Tanaman panili dapat diusahakan pada berbagai jenis tanah seperti andosol, latosol, podsolik, regosol dan jenis tanah lainnya, asalkan sifat fisiknya baik. Tingkat kesuburan tanah merupakan faktor kedua yang mempengaruhi pertumbuhan panili. Tanah yang rendah dengan solum yang relatif dalam dan mengandung bahan organik tinggi, sangat baik untuk pertumbuhan tanaman panili. Kemasaman tanah $(\mathrm{pH})$ yang dikehendaki berkisar antara 5.5-7.0 (Hadipoentyanti et al. 2007).

\section{BAHAN TANAM}

Pemecahan masalah keterbatasan bahan setek untuk pengembangan tanaman panili secara vegetatif juga dilakukan dengan melakukan penelitian mengenai penggunaan setek pendek mulai dari setek 1 buku sampai 3 buku (2 ruas). Somantri dan Evizal (1987) meneliti penggunaan setek 1,2 , dan 3 buku dan hasilnya tidak berbeda nyata baik parameter setek yang tumbuh, panjang tunas, panjang akar, dan jumlah ruas. Penggunaan stek 1 ruas atau 2 buku telah dilakukan pula oleh Rosman dan Tasma (1988) yang menunjukkan bahwa setek 1 ruas (2 buku) dengan 1 daun lebih baik dari pada tanpa daun yang ditunjukkan oleh pertumbuhan panjang tunas dan jumlah daun pada umur 3 dan 4 bulan setelah tanam. Pemangkasan pucuk 4 dan 6 minggu sebelum pengambilan setek panili telah dilakukan oleh Somantri dan Evizal (1988) dalam upaya meningkatkan mutu setek. Hasil penelitiannya menunjukkan bahwa pemangkasan sulur-sulur panili sebelum diambil sebagai bahan setek ternyata berpengaruh nyata terhadap jumlah setek yang tumbuh, panjang tunas 
maupun jumlah daun. Perlakuan pemangkasan pucuk (topping) 6 minggu lebih baik dari 4 minggu (Tabel 3).

Penggunaan bahan setek dari ruas ke-3 sampai ke-7 menjadi rekomendasi sebagai bahan perbanyakan vegetatif, persentase tumbuh tertinggi diperoleh pada posisi ruas ke-7 (92.92\%) dan Jumlah ruas tertinggi (7.57) diperoleh pada posisi ruas ke-3 (Sukarman dan Melati 2009). Panili klon 1 (VAPL 0013), 2 (VAPL 0014), 3 (VAPL 0005), dan 4 (VAPL 0003) mempunyai daya tumbuh dan pertumbuhan tanaman yang tidak berbeda baik di pembibitan maupun di lapang. Umur fisiologis sulur 6 dan 12 bulan tidak berpengaruh terhadap pertumbuhan panili di pembibitan, dan di lapang. Posisi ruas berpengaruh terhadap daya tumbuh setek. Setek dari ruas ke-4 dan ke-5 mempunyai daya tumbuh tertinggi, yaitu 87.47 dan $84.58 \%$, sedangkan dari ruas ke-3 mempunyai daya tumbuh serta pertumbuhan tanaman terendah, yakni $69.17-70.18 \%$, sedangkan tinggi tanaman, jumlah daun, dan jumlah ruas berturut-turut 12.66 $\mathrm{cm}$, 3.31, dan 3.31. Setek ruas ke-8 mempunyai pertumbuhan tanaman yang terbaik diikuti setek ruas ke-6, ke-7, dan ke-8. Tinggi tanaman bibit dari ruas ke-8, ke-6, ke7, dan ke-9 berturut-turut 22.55, 21.95, 21.49, dan $20.72 \mathrm{~cm}$, sedangkan jumlah daun dan jumlah ruasnya berturut-turut 5.57, 5.44, 5.35, dan 5.10. Hasil penelitian ini menunjukkan bahwa setek yang berasal dari ruas ke-4 sampai ke-9 layak digunakan untuk bahan perbanyakan panili (Sukarman 2011).

\section{ZAT PENGATUR TUMBUH (ZPT)}

Zat pengatur tumbuh adalah salah satu bahan sintesis atau hormon tumbuh yang dalam jumlah tertentu mempengaruhi proses pertumbuhan dan perkembangan tanaman melalui pembelahan sel, perbesaran sel dan diferensiasi sel. Pemberian zat pengetur tumbuh (ZPT) auksin merupakan salah satu upaya untuk meningkatkan keberhasilan tanaman terutama pada perbanyakan tanaman secara vegetatif dengan menggunakan setek. Indikator keberhasilan perbanyakan dengan cara ini adalah tumbuhnya akar dan tunas. Zat pengatur tumbuh yang umum digunakan yaitu Rootone-F yang memiliki komposisi bahan aktif Naphtalena Acetic Acid (NAA) 0.067\%, 2-Metil-1Napthalene Acetotamida MNAD 0.013\%, Indole Butyric Acid IBA $0.057 \%$ dan Tetramithiuram disulfat (4\%), tetapi dapat juga menggunkan air kelapa maupun urin sapi. Penggunaan IBA lebih banyak memberikan keberhasilan dibandingkan dengan lainnya. Pemakaian NAA harus lebih berhati-hati karena NAA lebih kuat daya rangsangnya serta mempunyai selang konsentrasi yang sempit (Mariska et al. 1987). Pemakaian zat pengatur tumbuh dapat dilakukan dengan disemprotkan, dicelup cepat atau dicelup lambat, apabila digunakan konsentrasi tinggi maka dianjurkan memakai metode celup. IBA merupakan auksin sintetis yang efektif merangsang pertumbuhan akar pada sejumlah spesies tanaman (Hartman and Kester 2010).

Penelitian penggunaan zat pengatur tumbuh (ZPT) telah dilakukan dalam upaya meningkatkan pertumbuhan tanaman panili. Mariska et al. (1987) meneliti kemungkinan penggunaan zat pengatur tumbuh Indole Butyric Acid (IBA) pada setek panili. Hasil penelitiannya menunjukkan bahwa penggunaan IBA 500 dan 1000 ppm tidak memberikan pengaruh terhadap pertumbuhan setek panili 1 ruas dan tidak dapat meningkatkan persentase tumbuh, serta panjang dan jumlah akar yang dihasilkan pada 18 minggu setelah tanam. Selanjutnya hasil penelitian Somantri dan Evizal (1987) menunjukkan bahwa penggunaan atonik $100 \mathrm{ppm}$ dan dan IBA 0, 400, dan 800 ppm pada setek 1 sampai 3 buku belum mampu memberikan pengaruh yang nyata terhadap persentase tumbuh, panjang tunas, panjang akar, dan jumlah ruas pada 8 minggu setelah tanam. Interaksi antara penggunaan IBA dan jumlah buku menunjukkan adanya penghambatan pertumbuhan tunas pada setek 1 buku. Begitu juga penggunaan Rhizopon B dan Rootone F tidak berbeda nyata baik terhadap persentase setek tumbuh, panjang akar, maupun panjang tunas.

Hasil penelitian Asnawi et al. (1989) menunjukkan bahwa penggunaan air kelapa dengan konsentrasi 50\% sebagai zat pengatur tumbuh dengan cara merendam setek panili 1 ruas selama 4 jam dapat meningkatkan pertumbuhan setek panili dibandingkan dengan kontrol. Dwiwarni (1989) meneliti kemungkinan penggunan urin sapi sebagai zat pengatur tumbuh. Hasil penelitiannya menunjukkan bahwa perendaman setek panili 1 ruas kedalam larutan urin sapi dengan konsentrasi $5-10 \%$ selama 10 menit dapat meningkatkan pertumbuhan akar dan persentase setek bertunas. Selanjutnya Rosman et al. (1991) meneliti penggunaan zat pengatur tumbuh nitroaromatik pada setek panili 1 ruas berdaun tunggal. Hasil penelitiannya menunjukkan bahwa penggunaan zat pengatur tumbuh nitroaromatik 100, 200, dan 300 ppm tidak berpengaruh nyata terhadap pertumbuhan tanaman pada parameter panjang tunas, jumlah daun, lebar daun dan panjang akar. Kusumawardana (2008) menambahkan bahwa aplikasi Rootone-F pada setek panili mempengaruhi secara nyata keberhasilan setek di pembibitan. Semakin tinggi konsentrasi Rootone-F yang diberikan yaitu $0 \mathrm{~g} \mathrm{~L}^{-1}$ air, $3 \mathrm{~g}$ $\mathrm{L}^{-1}$ air, $6 \mathrm{~g} \mathrm{~L}^{-1}$ air, dan $9 \mathrm{~g} \mathrm{~L}^{-1}$ air, persentase setek berakar, persentase setek bertunas jumlah daun, panjang akar, dan jumlah akar makin tinggi nilainya. Penelitian Hidayat dan Hariyadi (2015) menunjukkan bahwa penggunaan zat pengatur tumbuh (auksin) sebesar 2000 ppm mampu menghasilkan pertumbuhan bibit yang lebih baik dibandingkan dengan konsentrasi lainnya yaitu 0 ppm dan 1000 ppm. Penggunaan auksin pada konsentrasi tersebut mampu meningkatkan pertumbuhan tanaman pada 
parameter persentase setek hidup, panjang tunas, diameter ruas, jumlah ruas, dan jumlah daun bibit panili.

\section{PEMUPUKAN}

Pemupukan merupakan salah satu kegiatan pokok dalam teknik budidaya karena sangat erat kaitannya dengan pertumbuhan dan perkembangan tanaman. Pupuk diberikan pada tanaman dengan tujuan menambah zat (unsur) hara yang dibutuhkan tanaman. Pupuk dibagi menjadi 2 jenis berdasarkan asalnya yaitu pupuk organik (pupuk kandang, kompos, humus, dan pupuk hijau) dan anorganik (pupuk Urea, TSP, SP-36, ZA, KCl, NPK dan Gandasil).

Pupuk kandang merupakan salah satu jenis pupuk organik yang berasal dari kotoran hewan. Pupuk kandang merupakan campuran kotoran padat, air seni, dan sisa makanan ternak (Soepardi 1983). Pemberian pupuk kandang sapi selain dapat menambah tersedianya unsur hara, juga dapat memperbaiki sifat fisik tanah. Beberapa sifat fisik tanah yang dapat dipengaruhi pupuk kandang antara lain kemantapan agregat, bobot volume, total ruang pori, dan daya pegang air. Pupuk kandang diberikan melalui akar biasanya dengan cara ditambahkan sebagai campuran pada media tanam setek panili.

Pupuk Urea, TSP, SP-36, ZA, KCL, dan NPK merupakan jenis pupuk anorganik yang merupakan pupuk hasil proses rekayasa secara kimia, fisik, dan atau biologis, dan merupakan hasil industri atau pabrik pembuat pupuk. Secara ringkas, pupuk anorganik merupakan semua jenis pupuk yang bahan penyusunnya merupakan hasil sintesis buatan (Deptan 2003). Pupuk anorganik diberikan melalui akar dengan cara dibenam atau ditebar pada tanah atau media tanam setek panili.

Pupuk daun merupakan bahan-bahan atau unsurunsur yang diberikan melalui daun dengan cara penyemprotan atau penyiraman pada tanaman agar dapat langsung diserap guna mencukupi bagi kebutuhan pertumbuhan dan perkembangan tanaman (Sutedjo 2002). Nutrisi yang diberikan lewat daun (foliar aplication) dapat segera diserap dan hasilnya dapat terlihat dalam sehari atau dua hari dengan efek residu kecil. Pemberian harus lebih sering dilakukan dari pada pemberian lewat tanah (Harjadi 1996). Pupuk daun dapat diaplikasikan pada setek panili setelah mempunyai 1 sampai 2 daun sempurna.

Penelitian pemupukan telah dilakukan dalam upaya mengatasi ketersediaan unsur hara dalam tanah. Pemupukan pada panili telah menunjukkan pertumbuhan bibit panili menjadi lebih baik. Penggunaan pupuk kandang mampu meningkatkan pertumbuhan tanaman panili di pembibitan. Hasil penelitian Rosma dan Tasma (1988) menunjukkan bahwa pemakaian pupuk kandang menghasilkan pertumbuhan setek panili lebih baik dari pada setek tanpa pemakaian pupuk kandang yang ditunjukkan oleh parameter pertumbuhan setek baik dari panjang tunas maupun jumlah daun pada 3 dan 4 bulan setelah tanam. Pumupukan dengan perbandingan media tanam tanah dan pupuk kandang 4:1 dapat meningkatkan pertumbuhan setek panili di pembibitan serta lebih efisien dari segi dosis yang lebih tinggi yaitu perbandingan 1:1. Rosman et al. (1992) menambahkan bahwa penggunaan pupuk kandang dan kompos dapat meningkatkan pembentukan dan pertumbuhan tunas, tetapi tidak dapat meningkatkan pertumbuhan akar setek panili dibandingkan dengan kontrol (tanpa pupuk organik). Selanjutnya hasil penelitian Dhalimi (2003) menunjukkan bahwa penggunaan $50 \mathrm{mg}$ sekam/polybag memberikan pertumbuhan terbaik, begitu juga penggunaan $50 \mathrm{mg}$ abu sekam/polybag yang ditunjukkan oleh parameter tinggi tanaman, jumlah daun dan diameter batang pada 4 sampai 16 minggu setelah tanam. Penggunaan sekam dan abu sekam diduga mampu menciptakan kondisi lingkungan yang kondusif untuk pertumbuhan bibit karena memberikan tambahan unsur hara, khususnya Si (silikat), C organik, N total dan $\mathrm{P}$ tersedia, $\mathrm{K}, \mathrm{Ca}, \mathrm{P}$, dan $\mathrm{Mg}$.

Rosman et al. (1991) menunjukkan bahwa dengan pemberian pupuk NK (3 gr Urea dan 3 gr $\mathrm{KCl}$ ) pada setek panili satu ruas berdaun tunggal dapat meningkatkan pertumbuhan tanaman panili pada parameter tinggi tanaman, luas daun dan panjang akar pada 24 minggu setelah tanam. Selanjutnya Ruhnayat dan Rosman (1993) meneliti penggunaan pupuk NPK di pembibitan yang menunjukkan bahwa setek panili sangat tanggap terhadap pemupukan. Pupuk N, P, dan K baik secara tunggal maupun interaksinya dapat meningkatkan panjang tunas setek panili. Interaksi antara tiga pupuk yang memberikan pertumbuhan terbaik adalah komposisi $2 \mathrm{~g} \mathrm{~N} /$ pot $+2 \mathrm{~g} \mathrm{P}_{2} \mathrm{O}_{5} /$ pot $+1 \mathrm{~g} \mathrm{~K}$ O/pot, sedangkan dosis interaksi antara dua pupuk yang terbaik adalah $2 \mathrm{~g} \mathrm{~N} /$ pot $+1 \mathrm{~g} \mathrm{~K}_{2} \mathrm{O}$ /pot. Interaksi antar $\mathrm{N}$ dengan $\mathrm{K}$ dan $\mathrm{N}$ dengan $\mathrm{P}$ nyata pengaruhnya, sedangkan pengaruh tunggal dan interaksi antara tiga pupuk tidak nyata.

Menurut Asnawi (1990) penggunaan protein hidrolisat mampu meningkatkan jumlah daun dan jumlah ruas panili. Protein hidrolisat adalah komponen aktif dari Sitozim crop plus yang merupakan pupuk pelengkap cair yang mengandung unsur hara mikro aktif ( $\mathrm{Fe}, \mathrm{Cu}, \mathrm{Mg}$, dan Co), mineral dan air. Menurut Dwinarni (1989) Penyemprotan 2 g/l Gandasil D dilakukan setiap 1 sampai 2 minggu sekali dapat meningkatkan pertumbuhan panili. Penyemprotan pupuk daun yang paling efektif dilakukan pada waktu sore atau malam hari, antara jam 16.00 sampai 20.00 .

Hasil penelitian Pujiharti et al. (1992) menunjukkan bahwa penyemprotan isomer natrium nitrofenol pada mata tunas dan seluruh permukaan daun panili dapat meningkatkan persentase setek, jumlah daun, tinggi tunas, 
dan berat kering tanaman. Penggunaan pupuk daun NPK Mg (15-11-15-1) dan zat tumbuh dengan bahan aktif isomer nitrofenol sampai konsentrasi 200 ppm dapat meningkatkan pertumbuhan. Selanjutnya Dwiwarni dan Asnawi (1994) menambahkan bahwa cara pemberian pupuk melalui daun berpengaruh lebih baik terhadap pertimbuhan setek panili yang ditunjukkan oleh parameter tinggi tunas, jumlah daun, jumlah ruas, dan berat kering tunas dari pada pemberian pupuk lewat tanah. Dosis pupuk NPK (15:15:15) $0.3 \%$ memberikan hasil yang terbaik dibanding dengan dosis lainnya $(0.1 \%, 0.2 \%, 0.4 \%$, dan $0.5 \%)$. Interaksi antara cara pemberian pupuk dan dosis pupuk tidak berpengaruh nyata terhadap semua parameter yang diamati. Selanjutnya hasil penelitian Rosman et al. (2004) menunjukkan bahwa pemupukan NPK majemuk dengan dosis $4.5 \mathrm{~g}$ NPK yang diberikan 3 minggu setelah tanam di pembibitan adalah yang terbaik bagi tanaman panili.

Pentingnya $\mathrm{Ca}$ dan $\mathrm{Mg}$ untuk pertumbuhan dan perkembangan tanaman panili (Tabel 2), maka juga dilakukan penelitian yang berhubungan dengan hal tersebut. Hasil penelitian Asnawi (1989) menunjukkan bahwa perlakuan kapur silikat $6 \mathrm{~g} / \mathrm{pot}$ dan TSP $0.22 \mathrm{~g} / \mathrm{pot}$ menghasilkan pertumbuhan bibit panili lebih baik yang ditunjukkan oleh parameter diameter batang, tinggi tanaman, jumlah ruas, dan jumlah daun dibandingkan dengan perlakuan lainnya $(0,2$, dan $4 \mathrm{~g} /$ pot kapur silikat) dan (0, $0.11 \mathrm{~g} /$ pot TSP). Selanjutnya hasil penelitian Rosman et al. (1995) menunjukkan bahwa penggunaan bahan kapur dolomit $\left(\mathrm{CaMg}\left(\mathrm{CO}_{3}\right)_{2} 6 \mathrm{~g} /\right.$ pot secara signifikan dapat meningkatkan pertumbuhan tanaman panili di pembibitan.

\section{MIKORIZA}

Penelitian penggunaan mikoriza telah dilakukan untuk mengetahui kompatibilitas mikoriza yang merupakan campuran dari Glomus sp, Glomus etunicatum, Gigaspora margarita, dan Acaulospora sp pada perakaran panili, serta pengaruh mikoriza dan konsentrasi NPK bagi pertumbuhan bibit panili dalam upaya efisiensi dalam penyerapan hara. Mikoriza arbuskula (MA) termasuk golongan endomikoriza yang mempunyai struktur hifa yang disebut arbuskula, sebagai tempat kontak dan transfer hara mineral antara jamur dan tanaman inangnya pada jaringan korteks akar. Adanya simbiosis mutualisme antara tanaman dan MA memungkinkan cendawan memperoleh fotosintat dari tanaman inang, sedangkan MA membantu tanaman dalam penyerapan hara dan air. Keuntungan tanaman yang terinfeksi MA antara lain adalah efisiensi serapan beberapa unsur hara meningkat, seperti $\mathrm{P}, \mathrm{K}, \mathrm{Zn}$, dan S. Hasil penelitian menunjukkan bahwa mikoriza yang digunakan cukup kompatibel terhadap perakaran panili tipe Anggrek dan Gisting. Tingkat infeksi mikoriza pada perakaran panili tipe Anggrek yang lebih tinggi menunjukkan kompatibilitasnya yang lebih tinggi dibandingkan pada tipe Gisting. Penggunaan mikoriza campuran (100 g/tanaman) nyata meningkatkan tinggi tanaman dan jumlah daun panili berumur 5 bulan sebelum tanam sebesar $32.4 \%$ dan $20.4 \%$ dibandingkan tanpa mikoriza. Selain itu perlakuan mikoriza dengan $1 \mathrm{~N}: 1 \mathrm{P}: 1 \mathrm{~K}, 1 \mathrm{~N}: 1 \mathrm{P}: 3 \mathrm{~K}$, dan $1 \mathrm{~N}: 2 \mathrm{P}: 3 \mathrm{~K}$ meningkatkan kandungan $\mathrm{P}$ daun sebesar $36.4 \%, 7.7 \%$ dan $41.7 \%$ dibandingkan tanpa mikoriza (Trisilawati dan Zaubin 2002).

Selanjutnya hasil penelitian Firman (2008) menunjukkan bahwa Inokulasi $50 \mathrm{~g}$ MA-p/tanaman dan $50 \mathrm{~g}$ mycofer/tanaman memberikan pengaruh yang positif terhadap pertumbuhan bibit dua klon panili, yang ditunjukkan oleh pengaruhnya yang nyata terhadap parameter pertumbuhan bibit pada umur 18 MST. Mikoriza mycofer yang merupakan MA campuran jenis Glomus etanicatum, Glomus sp., Gigaspora margarita dan Acaulospora sp. yang diinokulasikan pada bibit tanaman panili klon Anggrek dan Gisting pada umumnya menunjukkan pengaruh yang lebih baik dibandingkan dengan mikoriza MA-p dalam meningkatkan tinggi tanaman, jumlah daun, diameter batang, indeks luas daun, dan bobot kering biomassa.

\section{KESIMPULAN}

Berdasarkan hasil pemaparan diatas, maka dapat disimpulkan sebagai berikut:

1. Panili merupakan komoditi yang mempunyai nilai ekonomi tinggi dan dapat menjadi sumber pendapatan petani serta sebagai komoditi ekspor yang cukup besar perannya dalam menghasilkan devisa bagi negara sehingga perlu mendapat perhatian dalam pengembangannya.

2. Bibit merupakan salah satu faktor penentu keberhasilan dalam upaya pengembangan dan pengusahaan tanaman panili. Tingkat pertumbuhan dan keberhasilan perbanyakan tanaman panili secara setek di pembibitan di antaranya dipengaruhi oleh teknologi budidaya dan kondisi lingkungan, sehingga harus mengadopsi teknologi budidaya yang tepat serta memperhatikan kesesuaian lingkungan yang memenuhi persyaratan tumbuh tanaman panili.

3. Tanaman panili secara umum diperbanyak secara vegetatif, perbanyakan secara vegetatif banyak dilakukan untuk tujuan komersial dengan menggunakan bahan setek yang terdiri atas 1 sampai 3 ruas. Keuntungan yang diperoleh pada perbanyakan vegetatif yaitu sifat-sifat pohon induknya dipertahankan, cepat berproduksi, mudah dilaksanakan dan relatif murah.

4. Bahan setek varietas Pania 1 dan Pania 2 dapat digunakan sebagai pohon induk karena memiliki potensi produksi dan ketahanan terhadap faktor lingkungan dan perlu ditingkatkan mutunya dengan 
cara manipulasi seperti pemotongan pucuk, perendaman dalam larutan fungisida, bakterisida, dan pemakaian zat pengatur tumbuh (ZPT).

5. Upaya untuk mendukung keberhasilan serta pertumbuhan setek panili, telah dilakukan berbagai penelitian untuk mengurangi kendala-kendala yang ada dalam praktek budidaya khususnya pembibitan dengan menggunakan bahan setek. Misalnya dalam upaya menanggulangi keterbatasan bahan setek dengan penggunaan setek pendek, meningkatkan pertumbuhan dengan penggunaan zat pengatur tumbuh, mengatasi ketersediaan unsur hara dengan pemupukan baik lewat tanah maupun daun, dan efisiensi dalam penyerapan hara dengan menggunakan mikoriza.

\section{DAFTAR PUSTAKA}

Acquaah G. 2009. Horticulture: Principles and Practices. Ed. ke-4. New Jersey (US): Prentice Hall.

Asnawi R. 1989. Pengaruh pemberian kapur dan pupuk fosfat terhadap pertumbuhan tanaman panili pada tanah podsolik merah kuning. Pemb. Littri. 14(4):130-133.

Asnawi R. 1990. Pengaruh torehan dan sitozim seed plus terhadap pertumbuhan setek tiga tipe panili (Vanilla planifolia Andrews). Bul. Littro. 5(1):38-45.

Asnawi R, M.P. Yufdi, T. Somantri. 1989. Pengaruh air kelapa terhadap pertumbuhan setek panili. Pemb Littro. 15(2):79-83.

[Deptan] Departemen Pertanian. 2003. Pedoman penggunaan pupuk an-organik. Jakarta (ID). Deptan.

Dhalimi A. 2003. Pengaruh sekam dan abu sekam terhadap pertumbuhan dan kematian tanaman panili (Vanilla planifolia Andrews) di Pembibitan. Bul. Littro. 14(2):46-57.

[Ditjenbun] Direktorat Jenderal Perkebunan. 2008. Pedoman Teknis Budidaya Panili. Jakarta (ID): Ditjenbun.
Dwiwarni I. 1989. Pengaruh penggunaan urin sapi dan pupuk daun terhadap pertumbuhan setek panili. Pembr. Littri. 15(1):36-41.

Dwiwarni I, R. Asnawi. 1994. Pengaruh cara pemberian dan konsentrasi pupuk NPK terhadap pertumbuhan panili. Pembr. Littri. 10(2):30-34.

Firman C. 2008. Teknik inokulasi mikoriza arbuskula pada bibit panili. Bul. Teknik Pertanian. 13(2) 47-50

Hadipoentyanti E, A. Ruhnayat, L. Udarno. 2007. Teknologi Unggulan Panili. Bogor (ID): Puslitbangbun.

Harjadi S.S. 1996. Pengantar Agronomi. Jakarta (ID): Gramedia.

Hartman H.T, D.E. Kester. 2010. Plant Propagation: Principles and Practices. Ed ke-8. New Jersey. (US): Prentice Hall 727 p.

Hidayat A.Y, Hariyadi. Respon pertumbuhan bibit panili (Vanilla planifolia Andrews) terhadap aplikasi zat pengatur tumbuh dan pupuk cair NPK. Bul. Agrohorti. 3(1):39-46(2015).

Ingels J.E. 2000. Ornamental Horticulture: Science, Operations, and Management. Ed ke-3. New York (US): Delmar.

Kusumawardana A. 2008. Pengaruh konsentrasi rootone-f dan jenis media tanam terhadap pertumbuhan setek panili (Vanilla planifolia Andrews) [skripsi]. Bogor (ID): Institut Pertanian Bogor.

Lawani M. 1995. Budidaya dan Penanganan Pasca Panen Panili. Yogyakarta (ID): Kanisius

Mansur U. 2009. Teknik penggunaan naungan paranet untuk meningkatkan pertumbuhan dan produksi panili (Vanilla planifolia Andrews). Bul Teknik Pertanian. 14(2):76-79.

Mariska I, I. Darwati, H. Moko. 1987. Perbanyakan stek panili (Vanilla planifolia Andrews) dengan zat pengatur tumbuh pada berbagai media tumbuh. Ed. Khusus Littro. 3(2):89-94. pada tabel 5. 